\title{
Analysis of Lifestyle, Knowledge, Attitude, and Knowledge of Women Aged 20-50 Years Old with Vitamin D Deficiency-Insufficiency in North Sumatera, Indonesia
}

\author{
Dina Keumala Sari ${ }^{1}$, Zaimah Zulkarnaini Tala ${ }^{2}$, Sri Lestari ${ }^{3}$, Sunna Vyatra Hutagalung ${ }^{4}$, Ratna Akbari Ganie ${ }^{5}$, \\ Delina Sekar Harum ${ }^{6}$ \\ ${ }^{1,2}$ Nutrition Department, Faculty of Medicine University of Sumatera Utara, Indonesia \\ dina@usu.ac.id \\ zaimahclinnut@yahoo.com \\ ${ }^{3}$ Public Health Department, Faculty of Medicine University of Sumatera Utara, Indonesia \\ srilestari@yahoo.com \\ ${ }^{4}$ Parasitology Department, Faculty of Medicine University of Sumatera Utara, Indonesia \\ sunnavyatra@yahoo.com \\ ${ }^{5}$ Clinical Pathology Department, Faculty of Medicine University of Sumatera Utara, Indonesia \\ ganieratnaakbari@yahoo.com \\ ${ }_{6}^{6}$ Medical Education Study Program, Faculty of Medicine University of Sumatera Utara, Indonesia \\ Delinasekararumeymail.com
}

\begin{abstract}
Study showed that $95 \%$ women had serum level of 25(OH)D lower than normal and women have riskier lifestyle than men, this is based on women's lifestyle, such as avoiding sun rays, sunblock application, low vitamin D intake, and low physical activity. As result of the deficiency, there will be increasing number of metabolic disorders such as obesity and diabetes mellitus type 2 .

To discover lifestyle, knowledge, attitude, and action of women aged 20-50 years old with vitamin D deficiencyinsufficiency regarding risk of metabolic disorder caused by vitamin $D$ deficiency.

Cross-sectional study engaging 98 women participants with vitamin D deficiency-insufficiency. Lifestyle including avoiding sunlight, low physical activity, and sunblock application were assessed. The scoring was to assess knowledge, attitude and action of women aged 20-50 years old with vitamin D deficiencyinsufficiency regarding risk of metabolic disorder in Medan and then the result was analyzed.

The study engaged 98 women aged 20-50 years old with vitamin D deficiency-insufficiency, showed vitamin D level with mean $19.66 \pm 5.69 \mathrm{ng} / \mathrm{ml}$. There were $46.4 \%$ participants categorized into vitamin D deficiency and $53.6 \%$ participants categorized into vitamin D insufficiency. All subjects were found to be low on sun rays exposure, high incidence sunblock applicaton, low vitamin $D$ intake, and low physical activities. According to knowledge about risk of metabolic disorder, there were $\mathbf{4 2 . 3 \%}$ participants with sufficient knowledge and $\mathbf{5 7 . 7 \%}$ with deficient knowledge, and regarding attitude, $48.52 \%$ had negative attitude and $51.5 \%$ had positive attitude, regarding action, $24.7 \%$ was sufficient and $\mathbf{7 5 . 3 \%}$ was deficient. According to the analysis, there was no significant association between
\end{abstract}

action and knowledge, attitude and knowledge, but there was significant association between action and knowledge based on education $(p=0.01)$.

Lifestyle, sufficient knowledge, and action could be the caused of low vitamin D level. There was significant association between action and knowledge based on education, but didn't show any associations. Based on this result, knowledge needs to be improved in order to improve attitude and action with counseling or books that are easy to be understood about the importance of vitamin $D$.

Keywords - Vitamin D deficiency-insufficiency, knowledge, attitude, action, women

\section{INTRODUCTION}

The high prevalence of vitamin D deficiency and insufficiency in women has been reported in many studies. vitamin D deficiency $(\leq 37.5 \mathrm{nmol} / \mathrm{L})$ and insufficiency $(>37.5-\leq 50 \mathrm{nmol} / \mathrm{L})$ in $72.4 \%$ children [1]. Sari (2013) reported there were vitamin D deficiency $(<20 \mathrm{ng} / \mathrm{mL})$ and insufficiency $(20-32$ $\mathrm{ng} / \mathrm{mL}$ ) in $95 \%$ women with single nucleotide polymorphism in vitamin D receptor gene TaqI and BsmI in North Sumatera [2]. Then, there was a report that mean of vitamin $\mathrm{D}$ level in women in North Sumatera, Indonesia was $17.71 \mathrm{ng} / \mathrm{mL}$, this 
level was far lower than normal serum level of $25(\mathrm{OH}) \mathrm{D}$ for a country with sufficient sun exposure [3].

There are several factors that affect vitamin D level in body, such as obesity or high level of fat, study showed that there was association between body fat and vitamin D. High level of fat in adipose tissue which affects health is defined as obesity [4]. Obesity can be calculated by measuring body fat level with Bioelectrical Impedance/BI method or with simple method, which is calculating the body mass index (BMI). Study showed that with higher level of body fat, the serum level of $25(\mathrm{OH}) \mathrm{D}$ will be lower, because vitamin $\mathrm{D}$ is deposited in adipocyte cells and is difficult to transport to circulation so therefore the serum level is low [1].

The other factor was lifestyle; women's lifestyle poses more risk of developing vitamin D deficiency than men, for example, the use sunblock. Women use sunblock more as preventive lifestyle than men. Women also have more body fat than men [5], [6]. According to the foretold background, researcher is interested in analyzing level of knowledge, attitude and action of women aged 20-50 years old with vitamin $\mathrm{D}$ deficiency-insufficiency regarding risk of metabolic disorder caused by vitamin D deficiency in North Sumatera.

\section{METHODOLOGY}

\section{A. Study Design and Subjects}

This study was a case control study that conducted in North Sumatera, Indonesia on February to April 2015. The subjects of this study consisted of 98 healthy adult women with various type of occupations, obese and non-obese based on Body Mass Index (BMI), and taken purposively. The subject devided into 2 groups, 49 subjects in obese group and 49 subjects in non-obese group. The inclusion criteria were women within the range of 20-50 years old. Exclusion criteria were subjects with history of diabetes mellitus, myocardial infarction, renal or liver dysfunction. In addition to those exclusion criteria, subjects who were pregnant, lactating, or using medications that may alter lipid profile were also excluded.

Lifestyle factors including living area, sun ray exposure, dressing style, sunscreen application, physical activity, and vitamin D intake. The cumulative sun ray exposure per day was divided into three groups, $<60$ minutes and $\geq 60$ minuter per day. The cumulative sun ray exposure questions were about how long they were exposed to sun ray throughout the day.

The whole observation was carried out in the subject's home or workplace, living of area devided into two areas, which are rural and urban in North Sumatera, Indonesia. This study also included subjects with a variety type of occupations (indoors or outdoors). The subjects were included in the study after completing an interview. All subjects were also asked to write an informed consent approved by The Health Research Ethics Committee of the Faculty of Medicine, Sumatera Utara University (No. 120/KOMET/FK USU/2015).

\section{B. Nutrition Intake, Anthropometric Assesment, and Body Fat Percentage}

Nutrition intake was assessed using 24-hours food recall for two days (one on working day and one on holiday), and included in this assessment was the intake of vitamin D. Calculation was perfomed using Nutrisurvey 2005, including the data of Indonesian cuisine. Assessment of the vitamin $\mathrm{D}$ intake includes vitamin $\mathrm{D}$ obtained from meal sources and supplemental vitamin D.

Body Mass Index and body fat percentage was assessed using Body Composition Monitor with Scale (HBF-362, KaradaScan-Omron, Japan). Body Mass Index categories were based on Asia-Pacific criteria: Underweight $\left(<18.5 \mathrm{~kg} / \mathrm{m}^{2}\right)$, Normal weight $\left(18.5-22.9 \mathrm{~kg} / \mathrm{m}^{2}\right)$, overweight $(23-24.9$ $\left.\mathrm{kg} / \mathrm{m}^{2}\right)$, obese I $\left(25-29.9 \mathrm{~kg} / \mathrm{m}^{2}\right)$ and obese II $(\geq 30$ $\left.\mathrm{kg} / \mathrm{m}^{2}\right)$. In this study we used two criterias obese $\left(\geq 25 \mathrm{~kg} / \mathrm{m}^{2}\right)$ and non-obese $\left(<24.9 \mathrm{~kg} / \mathrm{m}^{2}\right)$. Height was measured using staturemeter device to count BMI [4].

Body fat percentage based on body fat mass represents the amount of body fat mass to total body weight. Categories for body fat calculation are normal $(<29.9 \%)$ and high $(\geq 30.0 \%)$.

\section{Knowledge, Attitudes, and Actions}

Knowledge, attitudes, and actions was assessed using questionnair sheet that containing three aspects. Categories of knowledge about vitamin D were high, moderate, and low based on the right 
and wrong answer. Categories of attitudes about how to increased 25(OH)D serum level with changing lifestyles were negative and positive. Categories of actions about how to act to increased absorption and metabolism of vitamin $\mathrm{D}$, were seldom, often, and always. Besides distribution of three aspects, information about education also taken to complete the association among those variables. Categories of education were junior high school, elementary/senior high school, and university graduate (Strata/S 1).

\section{Biochemistry Analysis}

In this study, we measured serum $25(\mathrm{OH}) \mathrm{D}$ level using chemilluminescent immunoassay (CLIA) technology (Diasorin, Stillwater, MN). This measurement can detect levels ranging from 4.0 and $150 \mathrm{ng} / \mathrm{mL}$, based on $3.90 \% \mathrm{CV}$ inter-assay precision. Serum $25(\mathrm{OH}) \mathrm{D}$ levels were categorized into: deficiency $(<20 \mathrm{ng} / \mathrm{mL})$, insuficiency (20-32 $\mathrm{ng} / \mathrm{mL})$, suficient $(32-54 \mathrm{ng} / \mathrm{mL})$, normal in sunny countries $(54-90 \mathrm{ng} / \mathrm{mL})$, excessive $(>100 \mathrm{ng} / \mathrm{mL})$ and intoxication (>150 ng/mL) [7].

\section{E. Statistical Analysis}

Numerical variables were used to indicate mean \pm standard deviation, while categorical variables were used to indicate the percentage values of proportion. Chi-square equation was used to look for a significant difference between the two groups $(p<0.05)$. Unpaired T-test was used to compare numerical data on both groups, with $(p<0.05)$. Pearson correlation test was used to look for correlation among variables and serum $25(\mathrm{OH}) \mathrm{D}$ level, and logistic regression analysis was used to look for prediction factors. This study used SPSS program (version 11.5; SPSS Inc, Chicago, IL) for data analysis.

\section{RESULTS}

Description of the subjects by age range of the subjects was $35.60 \pm 7.68$ years $($ mean \pm SD) with mean BMI of $25.49 \pm 4.70 \mathrm{~kg} / \mathrm{m}^{2}$, and mean serum 25(OH)D level 19.66 $\pm 5.69 \mathrm{ng} / \mathrm{mL}$., The non-obese group with age range of $33.5 \pm 8.11$ years and the obese group with age range of $37.71 \pm 6.64$ years, with significant different between two groups $(p=0.001)$. There were significant differences in systolic blood pressure, abdominal circumference, and body fat percentage between $\mathrm{OG}$ and $\mathrm{NG}$ groups. Serum $25(\mathrm{OH}) \mathrm{D}$ and calcium level did not show any significant differences $(p=0.6$ and $p=0.9$, respectively). It was apparent that the low level of serum $25(\mathrm{OH}) \mathrm{D}$ was not affected by the amount of body fat Table 1.

TABLE I

GENERAL CHARACTERISTIC OF SUBJECTS

\begin{tabular}{|c|c|c|c|c|}
\hline Parameters & $\begin{array}{l}\text { All } \\
\mathrm{n}=98\end{array}$ & $\begin{array}{l}\mathrm{OG} \\
\mathrm{n}=49\end{array}$ & $\begin{array}{l}\mathrm{NG} \\
\mathrm{n}=49\end{array}$ & $\begin{array}{l}p- \\
\text { value }\end{array}$ \\
\hline Age (years) & $35.6 \pm 7.6$ & $37.7 \pm 6.6$ & $33.5 \pm 8.1$ & $0.01^{*}$ \\
\hline Anthropometry & & & & $001^{*}$ \\
\hline $\begin{array}{l}\text { BMI }\left(\mathrm{kg} / \mathrm{m}^{2}\right) \\
\text { Waist } \\
\text { circumference }\end{array}$ & $25.4 \pm 4.7$ & $29.1 \pm 3.7$ & $21.8 \pm 1.8$ & $0.01^{\prime \prime}$ \\
\hline (cm) & $83.3 \pm 11$ & $91.2 \pm 8.7$ & $75.4 \pm 6.4$ & $0.07^{*}$ \\
\hline $\begin{array}{l}\text { Body fat } \\
\text { percentage }(\%)\end{array}$ & $31.9 \pm 5.4$ & $35.9 \pm 3.3$ & $28.1 \pm 4.1$ & $0.001^{*}$ \\
\hline $\begin{array}{l}\text { Nutrient intake } \\
\text { per day }\end{array}$ & & & & \\
\hline $\begin{array}{ll}\text { Vitamin } & \text { D } \\
\text { intake }(\mu \mathrm{g}) & \end{array}$ & $5.2 \pm 6.9$ & $4.6 \pm 5.5$ & $5.8 \pm 8.1$ & 0.1 \\
\hline $\begin{array}{l}25- \\
\text { hydroxyvitamin }\end{array}$ & & & & \\
\hline $\begin{array}{l}\text { D serum } \\
(\mathrm{ng} / \mathrm{mL})\end{array}$ & $19.7 \pm 5.7$ & $19.3 \pm 5.9$ & $19.1 \pm 7.9$ & 0.9 \\
\hline
\end{tabular}

In Table 2, based on the comparison of both groups, it was apparent that body fat were associated with the development of obesity. In vitamin D categories, there were no differences between obese and non-obese group in terms of the development of vitamin D deficiency-insufficiency. The distribution of serum 25(OH)D level did not show any normal levels of $25(\mathrm{OH}) \mathrm{D}$, and only eight of all 98 subjects reached sufficient level. There were no subjects with normal or excessive level of $25(\mathrm{OH}) \mathrm{D}$ found in this study. There were associations between deficiency-insufficiency vitamin $D$ with living area, type of occupation, sun ray exposure, physical activity ( $p=0.014$; OR:6.25; CI 95\% 1.216-32.120). Prediction factors for low serum $25(\mathrm{OH}) \mathrm{D}$ level were vitamin $\mathrm{D}$ intake ( $p=0.012$; OR:5.43; CI 95\% 1.268-23.29), and body fat percentage (0.003; OR:14.14 CI 95\% 1.69 118.19). 
TABLE II

ASSOCIATION BETWEEN VITAMIN D DEFICIECNY AND LIFESTYLE

\begin{tabular}{|c|c|c|c|}
\hline Lifestyle factors & $\begin{array}{c}\text { Vitamin D } \\
\text { deficiency- } \\
\text { insuficiency } \\
\mathrm{n}=93 \\
\mathrm{n}(\%)\end{array}$ & $\begin{array}{c}\text { Vitamin D } \\
\text { sufficiency } \\
\mathrm{n}=5 \\
\mathrm{n}(\%)\end{array}$ & $p$-value \\
\hline \multicolumn{4}{|l|}{ Living area } \\
\hline Rural & $30(32)$ & 0 & $0.001^{*}$ \\
\hline Urban & $63(68)$ & $5(100)$ & \\
\hline \multicolumn{4}{|l|}{ Occupation } \\
\hline Indoors & $67(72.3)$ & 0 & $0.001^{*}$ \\
\hline Outdoors & $31(27.7)$ & $5(100)$ & \\
\hline \multicolumn{4}{|l|}{ Sun exposure per day } \\
\hline$\leq 60$ minutes & $47(50.7)$ & 0 & $0.007^{*}$ \\
\hline$>60$ minutes & $51(49.3)$ & $5(100)$ & \\
\hline \multicolumn{4}{|l|}{ Dressing style } \\
\hline Wearing hijab & $57(61.5)$ & $3(62.5)$ & 1.00 \\
\hline Not wearing hijab & $41(38.3)$ & $2(37.5)$ & \\
\hline \multicolumn{4}{|l|}{ Sunscreen application } \\
\hline Yes & $69(74.3)$ & $4(87.5)$ & 0.680 \\
\hline No & $29(25.7)$ & $1(12.5)$ & \\
\hline \multicolumn{4}{|l|}{ Physical activity } \\
\hline Low & $63(67.6)$ & $1(25)$ & $0.014^{*}$ \\
\hline Moderate & $35(32.4)$ & $4(75)$ & \\
\hline \multicolumn{4}{|l|}{ Vitamin D intake } \\
\hline Less & $79(84.5)$ & $3(62.5)$ & $0.012^{*}$ \\
\hline Moderate & $19(15.5)$ & $2(37.5)$ & \\
\hline
\end{tabular}

Table 3 showed that there were two correlations found, which were sun ray exposure and physical activity. Correlation between serum 25(OH)D level with sun ray exposure showed strong correlation and weak correlation between serum 25(OH)D level with physical activity.

TABLE III

CORRELATION ANALYSIS AMONG 25(OH)D SERUM WITH LIFESTYLES FACTORS

\begin{tabular}{|l|c|c|}
\hline \multicolumn{1}{|c|}{ Lifestyle factors } & $\boldsymbol{r}$ & $\boldsymbol{p}$ \\
\hline Sun ray exposure & 0.739 & $\mathbf{0 . 0 0 1}$ \\
\hline Physical activity & 0.338 & $\mathbf{0 . 0 0 1}^{*}$ \\
\hline Vitamin D intake & 0.044 & 0.587 \\
\hline \multicolumn{2}{|c|}{ Analysis using Pearson's correlation; significant value: $p<0.05$} \\
Correlations: weak ( $r<0.4)$, moderate $(\mathrm{r}=0.4-0.6)$, strong $(\mathrm{r}>0.6)$
\end{tabular}

According to knowledge about risk of metabolic disorder, there were $42.3 \%$ participants with sufficient knowledge and $57.7 \%$ with deficient knowledge, and regarding attitude, $48.52 \%$ had negative attitude and $51.5 \%$ had positive attitude, regarding action, $24.7 \%$ was sufficient and $75.3 \%$ was deficient. Table 4 showed that there was an association between knowledge and education $(p=0.01)$, but there were no association among knowledge, attitudes, and actions. Based on analysis, subjects had low knowledge about vitamin $\mathrm{D}$ which were low (57.7\%), action about how to increased $25(\mathrm{OH}) \mathrm{D}$ serum level with changing lifestyles were positive $(51.5 \%)$, and seldom/less actions about how to act to increased absorption and metabolism of vitamin D $(75.3 \%)$.

TABLE IV

ASSOCIATION BETWEEN KNOWLEDGE AND EDUCATION

\begin{tabular}{|c|c|c|c|c|}
\hline \multirow[b]{2}{*}{ Knowledge $^{c}$} & \multicolumn{3}{|c|}{ Education } & \multirow{2}{*}{$\begin{array}{l}\text { Total } \\
\mathrm{n}(\%)\end{array}$} \\
\hline & $\begin{array}{c}\text { Junior High } \\
\text { School } \\
\mathrm{n}(\%)\end{array}$ & $\begin{array}{c}\text { Elementary/Senior } \\
\text { High School } \\
\text { n }(\%)\end{array}$ & $\begin{array}{l}\text { University } \\
\text { Graduate } \\
\text { (S1) } \\
\text { n }(\%)\end{array}$ & \\
\hline $\begin{array}{l}\text { Moderate } \\
\text { Low }\end{array}$ & $\begin{array}{c}4(8.3) \\
44(40.2)\end{array}$ & $\begin{array}{l}6(6.2) \\
4(4.1)\end{array}$ & $\begin{array}{c}32(27.8) \\
8(13.4)\end{array}$ & $\begin{array}{c}42 \\
(42.8) \\
56 \\
(57.2)\end{array}$ \\
\hline Total n(\%) & $48(48.5)$ & $10(10.3)$ & $40(41.2)$ & $\begin{array}{c}98 \\
(100)\end{array}$ \\
\hline \multicolumn{5}{|c|}{$p$ value with significance $=0.01^{*}$} \\
\hline
\end{tabular}

\section{IV.DISCUSSION}

This study was conducted in the Sumatera Island (North Sumatera, Indonesia), in the $3.57^{\circ} \mathrm{N}$ latitude and $98.65^{\circ} \mathrm{E}$ longitude. Average temperature was $\pm 32^{\circ} \mathrm{C}\left(90^{\circ} \mathrm{F}\right)$ with efficient Ultra Violet (UV) B exposure for absorption and producing sufficient amount of vitamin D3 [8], [9]. In this study, reported that the low level of serum $25(\mathrm{OH}) \mathrm{D}$ may occur in tropical countries (rural and urban) with abundant sun ray exposure apart from whether the women are obese or not.

In this study, low serum $25(\mathrm{OH}) \mathrm{D}$ level was found in women with high body fat percentage, and the same result was also found in women with normal body fat percentage. Corresponding to the fact that fat may cause low level of serum $25(\mathrm{OH}) \mathrm{D}$, it was apparent in this study that lifestyle factors such as avoiding sun rays, low level of physical activities and low intake of vitamin $\mathrm{D}$ were also factors contributed to low level of serum $25(\mathrm{OH}) \mathrm{D}$. Studies showed contrasting association between 
serum 25(OH)D level and the BMI [1], [10], 11]. This was due to the fact that high amount of body fat caused low level of vitamin D in the circulation by trapping vitamin $\mathrm{D}$ inside adipose cells [12].

A person with high amount of body fat has 14 times greater chance to develop vitamin D deficiency than a person with normal amount of body fat. However, even though low level of vitamin $\mathrm{D}$ was associated with the amount of body fat, most of the subjects with low amount of body fat also developed vitamin D deficiency. This indicated that there were other factors besides body fat amount causing a woman with normal or low amount of body fat to develop vitamin $\mathrm{D}$ deficiency.

A previous study found similar result, which was a contrasting association between serum 25(OHD) level and BMI in accordance to age, especially in boys. The association produced risk factor of 5,958 times more likely of developing vitamin D deficiency with appropriate BMI for older age [1]. Another factor associated with this condition was low intake of vitamin D. Vitamin D fortified meal was said to be consumed in very little amount. Other factors included sun ray exposure, indoor activities, and dressing style [3].

Women have greater risk for having vitamin D deficiency, due to women's lifestyles which tend to spend more time indoors and avoiding sun rays. Not only housewives but also working women spend more time indoors than outdoors. Subjects who work outdoors also avoid sun rays exposure by shading from sun ray. However, in this study, sun rays avoidance was more strongly associated with vitamin D deficiency compared to low vitamin D intake

Sunscreen is more widely used by women than men. A study reported that with reasonable action theory, men and women were different in behavior, beliefs and normative beliefs [5]. The study found that women were more aware of sunscreen usage as a preventive measure than men, who were more reactive in style. In our study indirectly found that the reason of sunscreen usage was not to avoid skin cancer, but more directed towards cosmetics reason. The perception that whiter skin is more beautiful has greater impact on a woman's confidence compare to a darker skin (interview result).
According to a study, the inability to buy vitamin $\mathrm{D}$ food sources was a cause of vitamin D deficiency [13]-[17]. In our study, food sources found on assessment of nutritional intake of the subjects in this study were egg yolk, fish, and meat. Salmon and fish oil were expensive food sources in the market. Mushroom can be easily obtained, but for some region, such as Sumatera, mushroom is not regularly consumed.

This study revealed correlations among vitamin $\mathrm{D}$ and other contributing factors, the strong correlation found in sun ray exposure and the weak correlation found in physical activity. It was apparent that there was a correlation between physical activities with serum 25(OH)D level, but the correlation was weak. This study supported that physical activity was independent of sun ray exposure in increasing vitamin $\mathrm{D}$ activity. The synthesis of vitamin D in the skin highly requires an increase in skin temperature, thus increased metabolism from high level of activities may contribute in the conversion of vitamin D [17]-[20].

Most of the study subjects have low or moderate level of physical activities, and none of them reached the required level. The association between serum 25(OH)D level and physical activities showed 6 times greater probability of a woman developing vitamin D deficiency when she has low level of physical activities compared to moderate level of physical activities [21], [22].

This study also found the probability that low level of physical activities was due to the subjects' occupations. It was clear that the occupation affected the subjects in the sense that their work schedule prevented them from having time to workout. Another possibility was that their job did not involve a lot physical movements, causing low score on the level of physical activities.

Vitamin D intake was a predictive factor of the development of vitamin D deficiency, main food source for this vitamin is fortified milk. Another factor that was found to be strongly correlated with the level of vitamin D was continuous physical activities. It was said that, compared to the exposure of sun rays, a continuous physical activity can maintain the body status of vitamin D [22]. In our study, by using logistic regression method, factors which were found to be predictive for the 
likelihood of a person to develop vitamin D deficiency were body fat amount and vitamin D intake. Besides these factors, polymorphism of vitamin $\mathrm{D}$ receptor gene also an important factor that influenced $25(\mathrm{OH}) \mathrm{D}$ serum levels in the circulation [23], [24], but in this study we did not asses this parameter and this may become a limitation.

Knowing process after understanding an objects using eyes and ears. Knowing a problem is very important to forming an action [25]. However, if in public community lack of knowledge about vitamin $\mathrm{D}$, it will resulting a health problem, even in higher education. This study showed there were no association between knowledge, attitudes, and action, but there were association between knowledge and education, yet it still found higher deficiency-insuficiency vitamin D.

Knowledge is associative thinking process which connects or composes a thought based on facts or with another thought based on recurring experiences without the comprehension of causality which is real and universal. Knowledge is gained from human's curiosity, observation and experience regarding self and environment. Knowledge is gained by observing phenomenon with sense. All things are gathered in human self, since human is conscious about self until old or lifelong [25].

Measurement of knowledge can be done with interview or form which asks about material that wants to be measured from participants. The depth of knowledge known from this study shows that knowledge regarding risk of metabolic disorder is still low. In this study, regarding of metabolic disorders, the lack of knowledge, attitude and action is an encouragement to increase counseling so vitamin D deficiency-insufficiency in women aged 20-50 years old can be prevented.

Based on these data, this study resulting an information about lifestyle in adult women that influence vitamin D status in the circulation, no matter she is obes or not and higher education or not they have higher risk to be deficiencyinsuficiency vitamin D.

\section{V.CONCLUSIONS}

The result of this study showed that we can only found $25(\mathrm{OH}) \mathrm{D}$ serum levels categorized as deficiency, insufficiency and sufficiency. There were associations between deficiency-insuficiency vitamin D with lifestyle factors which were living area, type of occupation, sun ray exposure, physical activity, vitamin D intake, and body fat. Lifestyle factors such as avoiding sun ray exposure and low physical activity are directly correlation with low serum $25(\mathrm{OH}) \mathrm{D}$ level. The amount of body fat and vitamin $\mathrm{D}$ intake can be used as predicting factors in women, especially in Indonesia. This study reported low knowledge, positive attitudes, and less action, but there was an association between knowledge and education.

\section{RECOMMENDATION}

Based on analysis, women should change their lifestyle which are type of occupation (outdoors), sun ray exposure ( $\geq 60$ minutes), and physical activity (moderate). Because of low knowledge about vitamin $\mathrm{D}$, there should be counceling or education program to change women's lifestyle by understanding what is vitamin $\mathrm{D}$, and the goal is to increase vitamin D status.

\section{ACKNOWLEDGMENT}

Author thank to Direktorat Jenderal Pendidikan Tinggi, Kementerian Pendidikan dan Kebudayaan, Indonesia (Grant No. 120/ST 2H//TL/DITLITABMAS/II), for its support and funding.

\section{CONFLICT OF INTEREST}

There is no funding sources or conflict of interest in this research

\section{REFERENCES}

[1] Khor GL, Chee WSS, Shariff ZM, Poh BK, Arumugam M, Rahman JA, and Theobald HE, "High prevalence of vitamin D insufficiency and its association with BMI-for-age among primary school children in Kuala Lumpur, Malaysia", BMC Public Health, 11: 95-103. 2011.

[2] Sari DK, Alrasyid HA, Lipoeto NI, and Lubis Z, "Is Micro Evolution in Tropical Country Women Resulting Low 25(OH)D Level?: A Cross Sectional Study in Indonesia", J Food and Nutr., 4: 1-7. 2013.

[3] Sari DK, Damanik HA, Lipoeto NI, and Lubis Z, "Occurrence of Vitamin D Deficiency among Woman in North Sumatera, Indonesia". Malaysian J Nutr,;20: 63-70, 2014.

[4] WHO-WPRO, "The Asia-Pacific perspective: Redefining obesity and its intervention" pp 22. Australia: Health Communications Australia Pte. Limited. 2000.

[5] Abroms L, Jorgensen CM, Southwell BG, Geller AC, and Emmons $\mathrm{KM}$, "Gender differences in young adult's beliefs about sunscreen use", Health Educ Behav.,30, 1: 29-43, 2003.

[6] Riset Kesehatan Dasar/Riskesdas,.Badan Penelitian dan Pengembangan Kesehatan, Departemen Kesehatan, Republik Indonesia, 2010.

[7] Grant WB and Holick MF, "Benefit and requirement of vitamin D for optimal health: A review", Altern Med Rev., 10: 94-111. 2005. 
[8] Weather of Indonesia, From

www.indonesia.com/whether_of_Indonesia.html [Retrieved FebruaryApril 2015].2015.

[9] World Atlas, From www.worldatlas.com/aatlas/htmfindlatlong.htm [Retrieved April 2015]. 2015.

[10] Bell NH, Epstein S, Greene A, Shary J, Oexmann MJ, and Shaw S, "Evidence of alteration of the vitamin D-endocrine system in obese subjects", J Clin Invest., 76: 370-373, 1985.

[11] Liel Y, Ulmer E, Shary J, Hollis BW, and Bell NH, "Low circulating vitamin D in obesity", Calcif Tissue Int., 43: 199-201. 1988.

[12] Wortsman J, Matsuoka LY, Chen TC, Lu Z, and Holick MF, "Decreased bioavailability of vitamin D in obesity", Am J Clin Nutr. 72: 690-693. 2000.

[13] Masood SH and Iqbal MP, "Prevalence of vitamin D deficiency in South Asia", Pak J Med Sci., 24 (6): 891-897. 2008.

[14] Al-Othman A. Al-Musharaf S, Al-Daghri N, Krishnaswamy S, Yusuf DS, Alkharfy KM, Al-Saleh Y, Al-Attas OS, Alokail MS, Moharram O, Sabico S, and Chrousos GP, "Effect of physical activity and sun exposure on vitamin D status of Saudi children and adolescents", BMC Pediatrics, 12:92-98, 2012.

[15] Brock K, Graubard B, Fraser DR, Weinstein SJ, Stolzenberg-Solomon RZ, Lim U, Tangrea JA, Virtamo J, Ke L et al., "Predictors of vitamin $\mathrm{D}$ biochemical status in a large sample of middle-aged male smokers from Finland", Eur J Clin Nutr., 64 (3): 280-288. 2010.

[16] Harinarayan CV, "Prevalence of vitamin D insufficiency in postmenopausal South Indian Women”, Osteoporosis Int., 16 (4): 397 402. 2005.

[17] Holick MF, "Vitamin D deficiency", N Engl J Med., 357: 266-281. 2007.

[18] Lips P, "Vitamin D deficiency and secondary hyperparathyroidism in the elderly: Consquences for bone loss and fractures and therapeutic implications", Endocr Rev., 22: 477-501. 2001.

[19] Marwaha RK, Tandon N, Reddy D, Reddy HK, Aggarwal R, Singh R, Sawhney RC, Saluja B, Ganie MA, and Singh S. "Vitamin D and bone mineral density status of healthy schoolchildren in Northern India", Am J Clin Nutr., 82:477-482. 2005.

[20] Ogunkulade WB, Boucher BC, Bustin SA, Burrin JM, Noorian K, Mannan N, and Hitman GA, "Vitamin D metabolism inperiphera blood mononuclear cells is influenced by chewing "betel nut" (Areca catechu) in vitamin D status", J Clin Endocr Metab, 91 (7): 2612-2617. 2006.

[21] Rahman SA, Chee WS, Yassin Z, and Chan SP,"Vitamin D status among postmenopausal Malaysian women", Asia Pac J Clin Nutr., 13 255-260. 2004

[22] Roy DK, Berry JL, Pye SR, Adam JE, Swarbrick CM, and King Y, "Vitamin D status and bone mass in UK South Asian women", Bone,40 (1): 200-204. 2007.

[23] Sachan A, Gupta R, Das V, Agarwal A, Pradeep K, Awasthi PK, and Bhatia V, "High prevalence of vitamin D deficiency among pregnant women and their newborns in Northern India", Am J Clin Nutr., 81:1060-1064. 2005.

[24] Vupputuri MR, Goswami R, Gupta N, Ray D, Tandon N, and Kumar N, "Prevalence and functional significance of 25-hydroxyvitamin D deficiency and vitamin D receptor gene polymorphisms in Asian Indians", Am J Clin Nutr., 83:1411-1419. 2006.

[25] Notoadmojo S, "Pendidikan dan perlaku kesehatan", Jakarta: Rineka Cipta, 2007. 